\title{
PERMASALAHAN PENDIDIKAN YANG ADA PADA GURU
}

\author{
Muhammad Yasir \\ Email: 2010128110002@mhs.ulm.ac.id \\ Program Studi Pendidikan IPS Fakultas Keguruan dan Ilmu Pendidikan \\ Universitas Lambung Mangkurat \\ Banjarmasin
}

\begin{abstract}
Abstrak
Pendidikan merupakan sesuatu hal yang memiliki peranan begitu penting dalam upaya meningkatkan kualitas sumber daya manusia. Dalam dunia pendidikan seorang guru merupakan salah satu faktor utama dalam aktivitas pembelajaran. Pada tulisan ini akan menjelaskan mengenai permasalahan yang terjadi pada guru dalam dunia pendidikan. Permasalahan pasti ada dalam setiap proses kehidupan. Permasalahan yang terjadi pada guru diantaranya yaitu kecerdasaan, emosi, dan stres kerja. Dalam permasalahan tersebut pastinya berdampak pada dirinya pribadi serta peserta didiknya nanti. Sehingga suatu upaya diperlukan untuk menagatasi permasalahan yang terjadi. Berbagai upaya yang dilakukan harus diusahakan dengan sungguh-sungguh agar berhasil. Keberhasilan suatu pendidikan akan mempengaruhi generasi penerus bangsa dimasa yang akan datang.
\end{abstract}

\section{PENDAHULUAN}

Pendidikan merupakan suatu hal yang pastinya ada dalam setiap waktu, tempat dan kesempatan. Dimana dalam pendidikan itu banyak kepentingan, peran serta fungsi yang akan berkaitan dengan kualitas sumber daya manusia. Dalam dunia pendidikan peran seorang guru sangatlah penting, karena bagaimana manusia di masa akan datang di pengaruhi oleh guru yang mengajar sekarang. Sehingga kondisi pendidikan berkaitan dengan seorang guru. Akan tetapi tidak sepenuhnya beban pendidikan di tanggung oleh guru. Karena pendidikan dipengaruhi oleh beragam faktor yang ada dalam kehidupan.

Kualitas pendidikan memiliki cakupan yang begitu luas, akan tetapi banyak yang hanya melihat dari luarnya saja. Proses pembelajaran yang baik tentunya akan menghasilkan kualitas yang baik pula. Proses pembelajaran yang baik didukung oleh berbagai faktor pendidikan, diantaranya tenaga pendidik, peserta didik, sarana dan prasarana pembelajaran, serta situasi kondisi lingkungan belajar. Guru merupakan suatu profesi yang tidak mudah dijalani, akan tetapi menjadi guru adalah suatu hal yang dapat mengembangkan serta meningkatkan kemampuan pribadi maupun peserta didik. Dimana tugas guru bukan hanya memberikan 
materi pelajaran, akan tetapi guru juga berperan sebagai fasilitator, mediator, motivator yang berguna agar dapat menumbuhkan kreativitas dan semangat belajar kepada peserta didik.

Pendidikan merupakan suatu hal yang sangat strategis untuk kemajuan suatu bangsa. Akan tetapi dalam rangka mewujudkan pendidikan yang menghasilkan sumber daya unggul banyak permasalahan yang akan menghadang. Permasalahan ada bukan tanpa sebab, permaslahan datang dari berbagai faktor. Salah satu faktor yang menjadi permasalahan adalah pada diri pribadi seorang guru. Guru memiliki peranan sangat penting dalam dunia pendidikan. Oleh karena itu, apabila terjadi suatu permasalahan pada guru, kemungkinan besar akan berdampak pada peserta didiknya juga. Guru sebagai seorang panutan bagi peserta didik harus mampu menghadapi berbagai permasalahan yang ada. Dengan mengatasi berbagai permasalahan, guru akan semakin kuat dan berkembang dalam menjalankan profesinya.

\section{PERAN GURU SEBAGAI TENAGA PENDIDIKAN}

Guru ialah peran utama dalam penerapan sistem pendidikan di sekolah, yang memiliki peranan yang sangat berarti untuk mencapai tujuan dari pendidikan. Guru dijadikan tempat kepercayaan yang begitu besar untuk mengubah dan meningkatkan kualitas sumber daya manusia. Guru memiliki dua fungsi utama yaitu mendidik dan mengajar. Mendidik berarti guru dapat merubah serta membentuk sikap, perilaku, dan kepribadian peserta didik. Sedangkan mengajar berarti guru sebagai pengajar yang menyampaikan berbagai ilmu pengetahuan dengan memakai strategi serta metode dalam pembelajaran. Sebagai seorang pengajar, guru tentunya harus menguasai beragam ilmu pengetahuan yang akan ia ajarkan kepada peserta didiknya.

Guru merupakan tenaga pendidikan yang berperan sebagai pembimbing, pengajar, motivator, serta teladan bagi peserta didiknya. Peran guru sebagai pendidik mencakup banyak hal dalam dunia pendidikan di sekolah. Sekolah merupakan tempat belajar mengajar yang sudah ditentukan atau direncanakan untuk mengembangkan berbagai aspek pada peserta didik, diantaranya yaitu kognitif, afektif dan psikomorik. Sekolah sebagai lembaga pendidikan, berperan untuk menciptakan sumber daya manusia yang unggul dan berkarakter. Dimasa sekarang ini teknologi informasi dan komunikasi berkembang sangat pesat. Yang mana menyebabkan suatu perubahan yang berdampak positif maupun negatif bagi kehidupan masyarakat.

Guru merupakan salah satu faktor utama yang mempengaruhi keberhasilan pendidikan. Dalam hal pembelajaran apabila guru tidak memiliki keterlibatan dalam pendidikan, maka pendidikan tidak akan bermakna apa-apa tanpa seorang guru. Guru dalam pendidikan tentunya memerlukan keahlian khusus. Dimana keahlian itu dapat dilihat dari cara mengajar, materi yang disampaikan, serta bagaimana tingkah lakunya. Teknologi membawa kearah yang lebih baik dan dapat pula membawa kearah yang sebaliknya. Penanaman nilai-nilai budaya bangsa diperlukan untuk bisa mengimbangi kemajuan teknologi dan seiring berjalannya masa.

Untuk itu, pembelajaran mengenai nilai-nilai budaya bangsa harus diajarkan oleh tenaga pendidikan. Agar terhindar dari dampak negatif dari lajunya globalisasi atau perkembangan 
zaman. Sehingga kuat dan tangguh dalam menghadapi perkembangan dunia, setiap pendidikan harus mempertahankan serta mengembangkan nilai-nilai bangsa dan membangun karakter bangsa. Sumber daya manusia yang lemah tidak akan dapat bersaing dalam kehidupan. Kemampuan peserta didik dalam bidang pengetahuan, sikap, dan keterampilan dipengaruhi oleh guru. Apabila seorang guru dengan benar dan tepat dalam proses pembelajaran, maka peserta didik akan lebih memahami dan mengerti apa yang disampaikan oleh guru.

Perubahan sosial terjadi seiring dengan perkembangan zaman. Suatu budaya pun dapat berubah seiring berjalannya waktu. Manusia yang sebelumnya tidak melek terhadap teknologi menjadi manusia yang dalam kehidupan sehari-hari pun tidak lepas dengan penggunaan teknologi. Seorang guru yang memiliki pemahaman serta mengerti akan pemanfaatan teknologi secara tepat dalam pembelajaran, akan memudahkan dalam proses pembelajaran tersebut. Apalagi dalam masa pandemi covid-19, teknologi pendidikan sangat berperan penting dalam aktivitas pembelajaran. Penggunaan teknologi dalam kegiatan pembelajaran memiliki dampak yang positif apabila dipakai sesuai dengan kebutuhan. Apabila seorang guru kurang memahami mengenai teknologi pendidikan, disarankan agar mengikuti pelatihan serta pengembangan yang mengarah terhadap teknologi.

\section{PERMASALAHAN YANG TERJADI PADA GURU}

Dalam dunia pendidikan tidak semua berjalan dengan lancar. Pastinya dalam setiap proses terjadi adanya permasalahan. Permasalahan pasti ada dalam kehidupan, dan tentunya dalam dunia pendidikan terdapat pula suatu permasalahan. Permasalahan yang terjadi pada bidang pendidikan terjadi di berbagai aspek, diantaranya yaitu, guru, peserta didik, proses pembelajaran, sarana dan prasana serta biaya. Akan tetapi permasalahan yang begitu fatal terjadi kepada guru. karena guru merupakan inti dari pendidikan, sehingga apa yang terjadi pada guru tentunya akan berdampak pada berbagai aspek dalam pendidikan.

Beberapa permasalahan yang terjadi pada guru diantaranya kecerdasan, emosi serta stres kerja yang dialami. Kecerdasan merupakan suatu hal diamana kemampuan seorang guru sangat diperlukan. Apabila seorang guru kurang cerdas dalam menghadapi perkara terkait pembelajaran ataupun masalah pribadinya, tentunya akan berdampak pada keberhasilannya dalam kegiatan belajar mengajar. Kecerdasan tentunya menjadi suatu permasalahan yang begitu berdampak pada kinerja seseorang. Untuk itu sebelum menjadi seorang guru, proses pembelajaran yang didapat sebaiknya diingat serta dimanfaatkan dengan sebaik mungkin.

Sedangkan emosi merupakan sesuatu yang pasti nya ada pada diri setiap orang. Emosi merupakan suatu perasaan yang menggambarkan suasana isi hati seseorang. Contoh dari emosi yaitu, marah, sedih, gembira, senang, dan lain sebagainnya. Emosi pada seorang guru memiliki peran yang begitu penting. Dalam kegiatan pembelajaran, sebaikanya guru dapat mengekpresikan emosinya di tempat dan waktu yang tepat. Apabila seorang guru meletakkan emosi nya di salah tempat dalam pembelajaran, itu akan berdampak pada dirinya sendiri dan tentunya peserta didik juga. Peserta didik harus diahadapi dengan emosi yang tepat, agar kita bisa memahami serta mengajar dengan baik dan tepat. 
Begitu pula dengan stres kerja yang dialami, hal itu juga merupakan suatu permasalahan yang dialami oleh kebanyakan guru. Stres kerja terjadi karena suatu perasaan yang dialami oleh guru yang diakibatkan situasi, kondisi, tindakan, serta suatu peristiwa yang menekan pada guru yang berasal dari berbagai faktor seperti lingkungan, organisasi, dan dirinya sendiri dalam menghadapi pekerjaan dan tanggung jawabnya pada pekerjaan dan tentunya berakibat pada emosi serta perilakunya. Seorang guru yang mengalami stres kerja tentunya akan mempengaruhi kinerjanya dalam aktivitas pembelajaran. Hal itu menjadi suatu permasalahan yang seharusnya dihindari, agar tidak terjadi suatu hal yang tidak diinginkan.

Dari berbagai permasalahan yang terjadi pada guru dapat dipahami bahwa setiap permasalahan akan timbul apabila terjadi suatu kesalahan atau kurang tepatnya suatu tindakan yang diambil. Dalam permasalahan tentunya pasti ada jalan keluarnya. Seseorang tidak akan dapat permasalahan yang tidak bisa diselesaikannya. Jadi dalam berbagai permaslahan yang terjadi pada guru pasti ada cara dalam mengatasi permasalahan tersebut. Untuk mengatasi berbagai permasalahan diperlukan upaya. Dimana dalam upaya itu guru harus berusaha serta siap dalam menghadpi berbagai perkara.

\section{UPAYA MENGATASI PERMASALAHAN YANG TERJADI PADA GURU}

Upaya merupakan suatu usaha yang dilakukan untuk mencapai suatu tujuan. Dalam tujuan mengatasi permasalahan yang terjadi pada guru upaya tentu saja perlu dilakukan. Upaya yang dapat dilakukan untuk mengatasi permasalahan yang terjadi pada guru diantaranya yaitu, bimbingan, musyawarah, serta penyesuaian tingkah laku. Upaya yang dilakukan akan berhasil apabila dilakukan dengan sungguh-sungguh dan benar. Sebagian besar guru akan saling membantu apabila terjadi permasalahan dalam aktivitas pembelajaran. Hal itu dikarenakan guru tidak bekerja seorang diri, dan tentunya ada teman kerja yang bisa mensupport nya ketika ada masalah.

Bimbingan merupakan salah satu upaya untuk mengatasi permasalahan yang terjadi pada guru. Bimbingan merupakan suatu upaya yang dilakukan dengan cara diarahkan oleh orang yang lebih banyak pengalaman dalam mengajar. Bimbingan dilakukan secara personal dan informal kepada guru yang terkait dengan permasalahan yang dihadapinya. Dengan bimbingan sikap serta tingkah laku guru akan terarah menjadi lebih baik lagi. Pelaksanaan bimbingan tentunya akan mempengaruhi terhadap permasalahan yang dihadapi seperti dari aspek kecerdasan. Dengan dibimbing guru akan semakin berkembang mengenai kecerdasannya.

Setelah itu, upaya yang dapat dilakukan adalah musyawarah. Musyawarah merupakan suatu cara mendapatkan kepustusan secara bersama dan disepakati oleh orang yang bermusyawarah. Dalam upaya mengatasi permasalahan pada guru musyawarah dapat dilakukan antar guru. dimana dalam musyawarah itu para guru akan berdiskusi mengenai cara penyelesaian permasalahan yang tepat. Permaslahan yang bisa diatasi dengan musyawarah misalnya terkait dengan emosi guru. dimana apabila guru kurang tepat meletakkan emosinya maka musyawarah dapat dilakukan. Sehingga para anggota musyawarah lainnya dapat membantu dan memberikan solusi dari permasalahannya itu. 
Dan yang ketiga yaitu penyesuain tingkah laku. Penyesuain tingkah laku sangat berguna untuk mengatasai berbagai permasalahan. Dengan menyesuaikan tingkah laku, guru dapat melakukan pembelajaran secara benar dan tepat. Permasalahan yang bisa diatasi dengan penyesuain tingkah laku diantaranya yaitu stres kerja. Dimana dengan menyesuaikan tingkah laku dengan pekerjaannya akan berdampak pada dirinya. Perasaan yang dialami seorang guru akan berubah apabila tingkah lakunya sesuai dengan ketentuan dan arahan dari bimbingan maupun musyawarah yang dilakukannya. Seorang guru perlu menyesuaikan perilakunya guna mengatasi permasalahan yang ia hadapi.

Dari sebagian cara atau upaya dalam menghadapi permasalahan yang terjadi pada guru akan terlaksana apabila dilakukan dengan baik dan benar. Baik dan benar yang dimaksud adalah dengan cara melakukan upaya tersebut dengan sungguh-sungguh dan sesuai dengan arahan atau bimbingan yang diterima. Tentunya akan sangat berguna upaya untuk mengatasi permasalahan yang terjadi pada guru. Setiap permasalahan pasti ada jalan keluarnya. Demikian pula dalam menjalani kehidupan setiap permasalahan yang dapat kita atasi akan membuat kita menjadi orang yang lebih baik serta kuat dan tangguh dalam menghadapi kehidupan dunia.

\section{KESIMPULAN}

Guru merupakan tenaga pendidikan yang berperan sebagai pembimbing, pengajar, motivator, serta teladan bagi peserta didiknya. Peran guru sebagai pendidik mencakup banyak hal dalam dunia pendidikan. Perubahan sosial terjadi seiring dengan perkembangan zaman. Suatu budaya pun dapat berubah seiring berjalannya waktu. Guru merupakan salah satu faktor utama yang mempengaruhi keberhasilan pendidikan. Dalam hal pembelajaran apabila guru tidak memiliki keterlibatan dalam pendidikan, maka pendidikan tidak akan bermakna apa-apa tanpa seorang guru. Guru dalam pendidikan tentunya memerlukan keahlian khusus. Dimana keahlian itu dapat dilihat dari cara mengajar, materi yang disampaikan, serta bagaimana tingkah lakunya Dalam dunia pendidikan tidak semua berjalan dengan lancar. Pastinya dalam setiap proses terjadi adanya permasalahan. Permasalahan pasti ada dalam kehidupan, dan tentunya dalam dunia pendidikan terdapat pula suatu permasalahan. Permasalahan yang terjadi pada bidang pendidikan terjadi di berbagai aspek, diantaranya yaitu, guru, peserta didik, proses pembelajaran, sarana dan prasana serta biaya.

Beberapa permasalahan yang terjadi pada guru diantaranya kecerdasan, emosi serta stres kerja yang dialami. Dari berbagai permasalahan yang terjadi pada guru dapat dipahami bahwa setiap permasalahan akan timbul apabila terjadi suatu kesalahan atau kurang tepatnya suatu tindakan yang diambil. Dalam permasalahan tentunya pasti ada jalan keluarnya. Seseorang tidak akan dapat permasalahan yang tidak bisa diselesaikannya. Upaya merupakan suatu usaha yang dilakukan untuk mencapai suatu tujuan. Dalam tujuan mengatasi permasalahan yang terjadi pada guru upaya tentu saja perlu dilakukan. Upaya yang dapat dilakukan untuk mengatasi permasalahan yang terjadi pada guru diantaranya yaitu, bimbingan, musyawarah, serta penyesuaian tingkah laku Dari sebagian cara atau upaya dalam menghadapi permasalahan yang terjadi pada guru akan terlaksana apabila dilakukan dengan baik dan benar. Baik dan benar yang dimaksud adalah dengan cara melakukan upaya tersebut dengan sungguh-sungguh dan sesuai dengan arahan atau bimbingan yang diterima. 


\section{REFERENSI}

Abbas, E. W. (2015). Menulis Menjinakkan Kegagalan.

Abbas, EW (2016). Etnopedagogi: Pendidikan Berbasis Kearifan Lokal.

Abbas, EW (2016). Membangun Pendidikan Berbasis Nilai-Nilai Nasionalisme.

Abbas, E. W. (Ed.). (2017). Membangun pendidikan. Fakultas Keguruan dan Ilmu Pendidikan, Universitas Lambung Mangkurat.

Abbas, E. W. (2018). Penguatan Pendidikan IPS Di Tengah Isu-Isu Global.

Abbas, EW (2019). Membangun Karakter Bangsa Melalui Pendidikan: Melanjutkan Seminar Internasional Pendidikan Karakter.

Abbas, E. W. (2020). Menulis Artikel Jurnal. Menulis Artikel Jurnal.

Abbas, E. W. (2020). Menulis di Otak dan Menuliskan Tulisan di Otak.

ABBAS, EW (2020). Depeloving Pendidikan Berbasis Nilai-nilai Nasionalisme Prosiding Seminar Internasional.

Ayomi, A. (2011). Inventarisasi Permasalahan Guru Pemula dan Upaya Guru Pakar serta Kepala Sekolah dalam Mengatasi Permasalahan Guru Pemula (terkait empat kompetensi guru dalam pembelajaran biologi di SMA negeri dan SMA swasta di wilayah Kabupaten Jember).

Darmadi, H. (2016). Tugas, peran, kompetensi, dan tanggung jawab menjadi guru profesional. Edukasi: Jurnal Pendidikan, 13(2), 161-174.

Kurniawan, R. Y. (2016). Identifikasi permasalahan pendidikan di Indonesia untuk meningkatkan mutu dan profesionalisme guru. Konvensi Nasional Pendidikan Indonesia, 1415-1420.

Mangkunegara, A. A. P., \& Puspitasari, M. (2015). Kecerdasan emosi guru, stres kerja, dan kinerja guru SMA. Jurnal Kependidikan: Penelitian Inovasi Pembelajaran, 45(2).

Juhji, J. (2016). Peran Urgen Guru dalam Pendidikan. Studia Didaktika, 10(01), 51-62.

Rahmawati, A. N. (2018). Identifikasi Masalah yang Dihadapi Guru dalam Penerapan Kurikulum 2013 Revisi di SD. Indonesian Journal of Primary Education, 2(1), 114-123. 